\title{
Expression of bone morphogenetic protein 2, 4, and related components of the BMP signaling pathway in the mouse uterus during the estrous cycle*
}

\author{
Yan $\mathrm{LI}^{\dagger}$, Quan-wei WEI, Jian-gang FENG, Mu-lin XU, Rui-hua HUANG ${ }^{\dagger \dagger}$, Fang-xiong SHI ${ }^{\dagger \ddagger}$ \\ (College of Animal Science \& Technology, Nanjing Agricultural University, Nanjing 210095, China) \\ †E-mail: liyan1314526@163.com; hrh2002@163.com; fxshi@njau.edu.cn \\ Received Nov. 16, 2013; Revision accepted May 11, 2014; Crosschecked June 19, 2014
}

\begin{abstract}
The objective was to investigate the expression of bone morphogenetic protein (BMP) family members in the mouse uterus during the estrous cycle by real-time polymerase chain reaction (PCR) and immunohistochemistry. Uterine samples from Swiss ICR mice were collected and dissected free of surrounding tissue. One uterine horn was snap frozen in liquid nitrogen immediately after collection and stored at $-80^{\circ} \mathrm{C}$ for RNA extraction, and the other was fixed in $40 \mathrm{mg} / \mathrm{ml}$ paraformaldehyde at room temperature for immunolocalization of BMP2 protein. Real-time PCR analysis showed that the expression level of $B m p 2$ was significantly higher at proestrus than at estrus and metestrus $(P<0.05)$. The relative abundance of $B m p 4$ exhibited significant fluctuations, but there were no statistically significant differences between the expression levels of $B m p 2$ and Bmp4 $(P>0.05)$. The expression levels of $B m p r 1 a$ and $B m p r 2$ remained unchanged during estrous cycles. However, the level of Bmpr1b mRNA decreased significantly at estrus $(P<0.05)$, increasing subsequently at metestrus. Furthermore, the level of Bmpr $1 b$ mRNA was significantly lower than those of Bmpr1a and Bmpr2 mRNA at the corresponding stages $(P<0.05)$. All three receptor-regulated Smads ( $R$-Smads) detected were differentially expressed in the mouse uterus and the expression levels of Smad1 and Smad5 were significantly higher than that of Smad8 $(P<0.05)$. In addition, the expression level of Smad4 did not change substantially throughout the estrous cycle. Immunohistochemical experiments revealed that BMP2 protein was differentially expressed and localized mainly in the uterine luminal and glandular epithelial cells throughout the estrous cycle. In conclusion, our results provide information about the variation in the mRNA levels of Bmp2 and Bmp4 and related components of the BMP signaling pathway. The data provide quantitative and useful information about the roles of endometrial BMP proposed and demonstrated by others, such as the degradation and remodeling of the endometrium.
\end{abstract}

Key words: Bone morphogenetic protein (BMP), BMP receptor, SMAD, Uterus, Estrous cycle doi:10.1631/jzus.B1300288 Document code: A CLC number: Q492.5

\section{Introduction}

The uterus is a major female hormone-responsive organ necessary for many pivotal reproductive events,

\footnotetext{
Corresponding authors

* Project supported by the National Natural Science Foundation of China (No. 31172206) and the Grant-in-Aid for Innovative Training of Doctoral Students in Jiangsu Province (No. CXLX13-287), China (c) Zhejiang University and Springer-Verlag Berlin Heidelberg 2014
}

such as embryo implantation, decidualization, placentation, and labor (Dey, 2004; Fernandez-Valdivia et al., 2007; Franco et al., 2008; Abdallah et al., 2012; Kong et al., 2012). Endometrial tissues undergo remarkable periodic growth, degeneration, and leucocytosis of the epithelial cells during the estrous cycle. These histological events are controlled by ovarian steroids. In addition, many of these processes are considered to be regulated by cytokines and growth factors, several of which are members of the 
transforming growth factor- $\beta$ (TGF- $\beta$ ) superfamily (Liu et al., 2004; Omwandho et al., 2010; Bukowska et al., 2011; Tanwar and McFarlane, 2011; Argañaraz et al., 2013).

The bone morphogenetic protein (BMP) family is the largest subgroup of ligands in the TGF- $\beta$ superfamily, which is closely associated with biological processes and cellular events involved in uterine cell proliferation, differentiation, apoptosis, and tissue remodeling (Shimasaki et al., 2004; Shimizu et al., 2004; Jones et al., 2006). More than 20 BMP isoforms have been identified, and they can be divided into four distinct subgroups based on the properties of their binding to type I receptors, including BMP2/4, BMP5/6/7/8, growth/differentiation factor (GDF)-5/6/7, and BMP9/10. Homo- or hetero-dimers of the BMP family ligands bind to and phosphorylate two types of serine/threonine kinase receptors to form complexes of transmembrane type I and type II receptors, which subsequently transmit signals from the cell surface to the cytoplasm (Aoki et al., 2001; Hu et al., 2003; Cai et al., 2012).

The Smad-dependent pathway involves canonical BMP signaling and mediates signals from the cytoplasm to the nucleus (Wen et al., 2011). SMAD proteins, the major intracellular signal transducers for the BMP family receptors, can be classified into three types: receptor-regulated SMADs (R-SMADs: SMAD1, SMAD5, and SMAD8), inhibitory SMADs (I-SMADs: SMAD6 and SMAD7), and a commonmediator SMAD (SMAD4) (Massague et al., 2005; Miyazono et al., 2010; Cai et al., 2012; Pangas, 2012). Once a ligand-receptor complex is formed, type-I receptors phosphorylate down-stream R-SMAD proteins. Phosphorylated R-SMADs form heteromeric complexes with SMAD4 (Co-SMAD) and translocate to the nucleus to regulate BMP-stimulated alterations in target gene expression through interaction with other factors, including transcription factors and transcriptional coactivators or corepressors (Xia et al., 2005; Bruce and Sapkota, 2012).

Several molecular and functional studies have suggested the presence of BMP family members in the mammalian uterus (Paria et al., 2001; Erickson et al., 2004; Lee et al., 2007). In situ hybridization results revealed that $B m p 7$ was highly expressed in the endometrium of the non-pregnant rat uterus (Erickson et al., 2004). A low level of Bmp5 mRNA has been detected in the stroma close to the myometrium and in the myometrial connective tissue (Paria et al., 2001). Bmpr mRNA appeared to show dynamic expression (Erickson et al., 2004), whereas Smad4 mRNA was constitutively expressed in the glandular and luminal epithelium throughout the estrous cycle (Liu et al., 2004). The differential distribution and expression of BMP family members in the uterus indicate their differing roles in the regulation of uterine function and development. There is an increasing evidence that BMP2 affects proliferation, differentiation, and apoptosis of endometrial cells (Lee et al., 2007; Franco et al., 2011) and that BMP4 may play an important role in the maintenance of the uterine endometrium (Tanwar and McFarlane, 2011). Although a series of studies have focused on BMP signaling, there is a lack of quantitative descriptions of BMP family members in the mouse uterus. To gain more experimental clues clarifying the molecular mechanisms of BMP signaling during the estrous cycle, we analyzed the temporal and spatial expression patterns of BMP family members by real-time polymerase chain reaction (PCR) and immunohistochemistry.

\section{Materials and methods}

\subsection{Experimental animals and sample preparation}

A total of 30 female Swiss ICR mice of similar age and weight were purchased from the Laboratory Animal Center of Nanjing Medical University, China. They were raised in an animal room with controlled temperature $\left(20-25^{\circ} \mathrm{C}\right)$ and lighting (12-h light/dark cycle), and were provided with commercial feed and tap water ad libitum. The various stages of the estrous cycle were monitored by vaginal smears. The body weights of the mice were recorded immediately before they were sacrificed. Uterine samples (at least seven mice per time point) were collected and dissected free of surrounding tissue. One uterine horn was snap frozen in liquid nitrogen immediately after collection and stored at $-80{ }^{\circ} \mathrm{C}$ for RNA extraction, and the other was fixed in $40 \mathrm{mg} / \mathrm{ml}$ paraformaldehyde at room temperature for immunolocalization of BMP2 protein. All experiments were carried out in accordance with the principles for the Care and Use of Laboratory Animals approved by the Institutional 
Animal Care and Use Committee of Nanjing Agricultural University, China.

\subsection{RNA isolation and reverse transcription}

Total RNA was extracted from all samples using a commercial RNA isolation kit (TaKaRa code: D9108A, Dalian, China) according to the manufacturer's instructions. Total RNA was dissolved in $60 \mu \mathrm{l}$ RNase-free deionized water $\left(\mathrm{dH}_{2} \mathrm{O}\right)$ and stored at $-80{ }^{\circ} \mathrm{C}$. Subsequently, $1 \mu \mathrm{g}$ of total RNA of high integrity (not degraded) and high purity (no contaminants) was reverse-transcribed into complementary DNA (cDNA) using reverse transcription reagent kits (TaKaRa code: RR047A, Dalian, China). Each PCR reaction contained $2.0 \mu \mathrm{l} 5 \times$ genomic DNA (gDNA) eraser buffer, $1.0 \mu \mathrm{l}$ gDNA eraser, $1 \mu \mathrm{g}$ total RNA, $1.0 \mu 1$ PrimeScript ${ }^{\mathrm{TM}} \mathrm{RT}$ enzyme mix $1,1.0 \mu \mathrm{l} \mathrm{RT}$ primer mix, $1.0 \mu \mathrm{l}$ RT primer mix, $4.0 \mu \mathrm{l} 5 \times$ PrimeScript ${ }^{\mathrm{TM}}$ buffer 2 , and sufficient RNase-free $\mathrm{dH}_{2} \mathrm{O}$ in a total volume of $20 \mu \mathrm{l}$. Reverse transcription cycle conditions were: $42^{\circ} \mathrm{C}$ for $2 \mathrm{~min}$ and $37^{\circ} \mathrm{C}$ for $15 \mathrm{~min}$. The reaction was terminated by incubation at $85{ }^{\circ} \mathrm{C}$ for $5 \mathrm{~s}$ and cooling at $4{ }^{\circ} \mathrm{C}$. The cDNA was stored at $-80{ }^{\circ} \mathrm{C}$ or used for real-time PCR immediately.

\subsection{Real-time PCR}

The mRNA expression patterns of BMP2, BMP4, and components of the BMP signaling pathway were assessed using a commercial real-time PCR kit (TaKaRa code: RR820A, Dalian, China) on an ABI StepOne ${ }^{\mathrm{TM}}$ real-time PCR machine (Applied Biosystems, Life Technologies Corporation, Grand Island, NY, USA). The primer pairs used for amplification of the target genes are listed in Table 1. The PCR amplification was performed in a total volume of $20 \mu 1$ containing $10 \mu \mathrm{l}$ SYBR Premix Ex Taq II, $6.0 \mu \mathrm{l}$ RNase-free $\mathrm{dH}_{2} \mathrm{O}, 2 \mu \mathrm{l}$ cDNA, $0.4 \mu \mathrm{l}$ ROX reference dye, and $0.8 \mu \mathrm{l}$ each of forward and reverse primer pairs. Each PCR cycle included a denaturation step at $95^{\circ} \mathrm{C}$ for $30 \mathrm{~s}$, followed by 40 cycles of $95^{\circ} \mathrm{C}$ for $5 \mathrm{~s}$ and extension at $60^{\circ} \mathrm{C}$ for $34 \mathrm{~s}$, and a dissociation step consisting of $95{ }^{\circ} \mathrm{C}$ for $15 \mathrm{~s}, 60{ }^{\circ} \mathrm{C}$ for $1 \mathrm{~min}$, and $95{ }^{\circ} \mathrm{C}$ for $15 \mathrm{~s}$. The real-time PCR was performed with three technical replicates per animal sample. Finally, the relative expression of each gene was standardized to glyceraldehyde-3-phosphate dehydrogenase (Gapdh).

Table 1 Primer sequences, GenBank accession Nos., and product sizes of genes selected for real-time PCR

\begin{tabular}{|c|c|c|c|}
\hline Target gene & Accession No. & Primer sequence $\left(5^{\prime} \rightarrow 3^{\prime}\right)$ & Product size (bp) \\
\hline \multirow[t]{2}{*}{ Gapdh } & NM_008084.2 & F: CATGTTCCAGTATGACTCCACTC & 136 \\
\hline & & R: GGCCTCACCCCATTTGATGT & \\
\hline \multirow[t]{2}{*}{ Bmp2 } & NM_007553.2 & F: TGACTGGATCGTGGCACCTC & 112 \\
\hline & & R: CAGAGTCTGCACTATGGCATGGTTA & \\
\hline \multirow[t]{2}{*}{ Bmp4 } & NM_007554.2 & F: TTTGTTCAAGATTGGCTCCCAAG & 101 \\
\hline & & R: AAACGACCATCAGCATTCGGTTA & \\
\hline \multirow[t]{2}{*}{ Bmprla } & NM_009758.4 & F: ATGGCCATTGCTTTGCCATTA & 126 \\
\hline & & R: TCCTGCGTAGCTGGGCTTTC & \\
\hline \multirow[t]{2}{*}{ Bmprlb } & NM_007560.3 & F: CTACGTTGTAAATGCCACCACCA & 118 \\
\hline & & R: AGGTGACAACAGGCATTCCAGA & \\
\hline \multirow[t]{2}{*}{ Bmpr2 } & NM_007561.3 & F: CAAATATCCTGGATGGCAGCAGTA & 141 \\
\hline & & R: TGGAGATGACCCAGGTGGAC & \\
\hline \multirow[t]{2}{*}{ Smadl } & NM_008539.3 & F: ACCTGTGGCTTCCGTCTC & 97 \\
\hline & & R: ATCGTGGCTCCTTCGTC & \\
\hline \multirow[t]{2}{*}{ Smad4 } & NM_008540.2 & F: CAGCACTACCACCTGGACTGGA & 145 \\
\hline & & R: CTGGAATGCAAGCTCATTGTGAA & \\
\hline \multirow[t]{2}{*}{ Smad5 } & NM_001164041.1 & F: AAGTAGATTCTGCCTGGGATT & 197 \\
\hline & & R: AGACGGTGGTGGGATGG & \\
\hline \multirow[t]{2}{*}{ Smad8 } & NM_019483.5 & F: ATCCCTGGCAATCTGTA & 169 \\
\hline & & R: CCCTGGCTGTCCTGTAA & \\
\hline
\end{tabular}




\subsection{Immunolocalization of BMP2 protein}

Immunohistochemistry was carried out using the streptavidin-biotin peroxidase complex (SABC) method to examine the immunolocalization of BMP2 protein in the mouse uterus during the estrous cycle. Paraffin-embedded uteri were cut into 6 - $\mu$ m-thick sections and mounted on slides. Sections were deparaffinised and hydrated by a consecutive series of xylene and ethanol, and treated with $9 \mathrm{mg} / \mathrm{ml}$ hydrogen peroxide to inactivate endogenous peroxidase activity. Sections were then incubated with $50 \mathrm{mg} / \mathrm{ml}$ bovine serum albumin (BSA) over $1 \mathrm{~h}$ to block non-specific staining. Subsequently, sections were incubated with a rabbit polyclonal antibody to BMP2 (Abcam Inc., Cambridge, MA, USA) at a dilution of 1:400 overnight at $4{ }^{\circ} \mathrm{C}$, and then incubated with a secondary antibody, goat anti-rabbit $\mathrm{IgG}$, diluted in phosphate buffer solution (PBS) over $2 \mathrm{~h}$ in a wet box at room temperature. Finally, immunoreactive signals were visualized by addition of diaminobenzidine substrate (DAB; Sigma Chemical Co., USA). Negative control sections were incubated with normal rabbit serum omitting the primary antibody. To distinguish the staining intensity of BMP2 protein among the different uterine structural components and cell types, sections were examined using a method similar to that described previously (Shi et al., 2004; Ding et al., 2012; Li et al., 2014): -, no staining; + , weak staining; ++ , moderate staining; +++ , strong staining. Relative levels of immunostaining were evaluated at least three times for each sampling stage.

\subsection{Statistical analysis}

All data were collected using Origin Pro 8.0 software (Origin Lab Corporation, USA). Data are presented as mean \pm standard error of the mean (SEM). For statistical evaluation of data, one-way analysis of variance (ANOVA) followed by the Tukey's post hoc test was applied to detect differences among stages for each gene. Paired-sample $t$-tests were performed for two-gene comparisons. Means identified with the same letter are not significantly different $(P>0.05)$.

\section{Results}

\subsection{Body weights of mice during the estrous cycle}

As shown in Table 2, the body weight of each mouse was nearly $30 \mathrm{~g}$, and there were no significant differences among different stages of the estrous cycle.

Table 2 Body weights of mice during the estrous cycle

\begin{tabular}{ccc}
\hline $\begin{array}{c}\text { Stage of } \\
\text { estrous cycle }\end{array}$ & $\begin{array}{c}\text { Number of } \\
\text { animals }\end{array}$ & $\begin{array}{c}\text { Body weight } \\
(\mathrm{g})\end{array}$ \\
\hline P & 7 & $28.47 \pm 0.59$ \\
E & 7 & $30.46 \pm 0.62$ \\
M & 8 & $28.84 \pm 0.93$ \\
D & 8 & $29.72 \pm 0.81$ \\
\hline
\end{tabular}

* Data are expressed as mean \pm SEM. P: proestrus; E: estrus; M: metestrus; D: diestrus

\section{2 mRNA expression patterns of Bmp2, Bmp4, and components of the signaling pathway during the estrous cycle}

To investigate the mRNA levels of BMP family members, real-time PCRs were performed in the mouse uterus during the estrous cycle. Our results showed that different members of the BMP family were differentially expressed in all studied stages of the estrous cycle.

The expression level of Bmp2 was significantly higher at proestrus $(\mathrm{P})$ than at estrus $(\mathrm{E})$ and metestrus (M) $(P<0.05$; Fig. 1). The relative abundance of Bmp4 showed significant fluctuations, strongly decreasing at estrus and diestrus (D) $(P<0.05)$, and strongly increasing at metestrus $(P<0.05)$. Paired-sample $t$-tests revealed that there were no statistically significant differences between the expression levels of Bmp2 and Bmp4.

The expression levels of Bmprla and Bmpr2 remained unchanged during an entire estrous cycle. However, the level of Bmprlb mRNA decreased significantly at estrus $(P<0.05)$, increasing subsequently at metestrus $(P<0.05)$. Furthermore, the level of Bmprlb mRNA was significantly lower compared with that of Bmprla and Bmpr 2 mRNA at the corresponding stages $(P<0.05)$.

The expression level of Smad1 did not change significantly at proestrus or estrus, whereas it increased markedly at metestrus $(P<0.05)$. The relative quantity of Smad4 did not change substantially throughout the estrous cycle. The expression level of Smad5 was significantly higher at metestrus than at other stages $(P<0.05)$. The relative quantity of $S$ mad 8 was lower at estrus than at diestrus $(P<0.05)$. In 

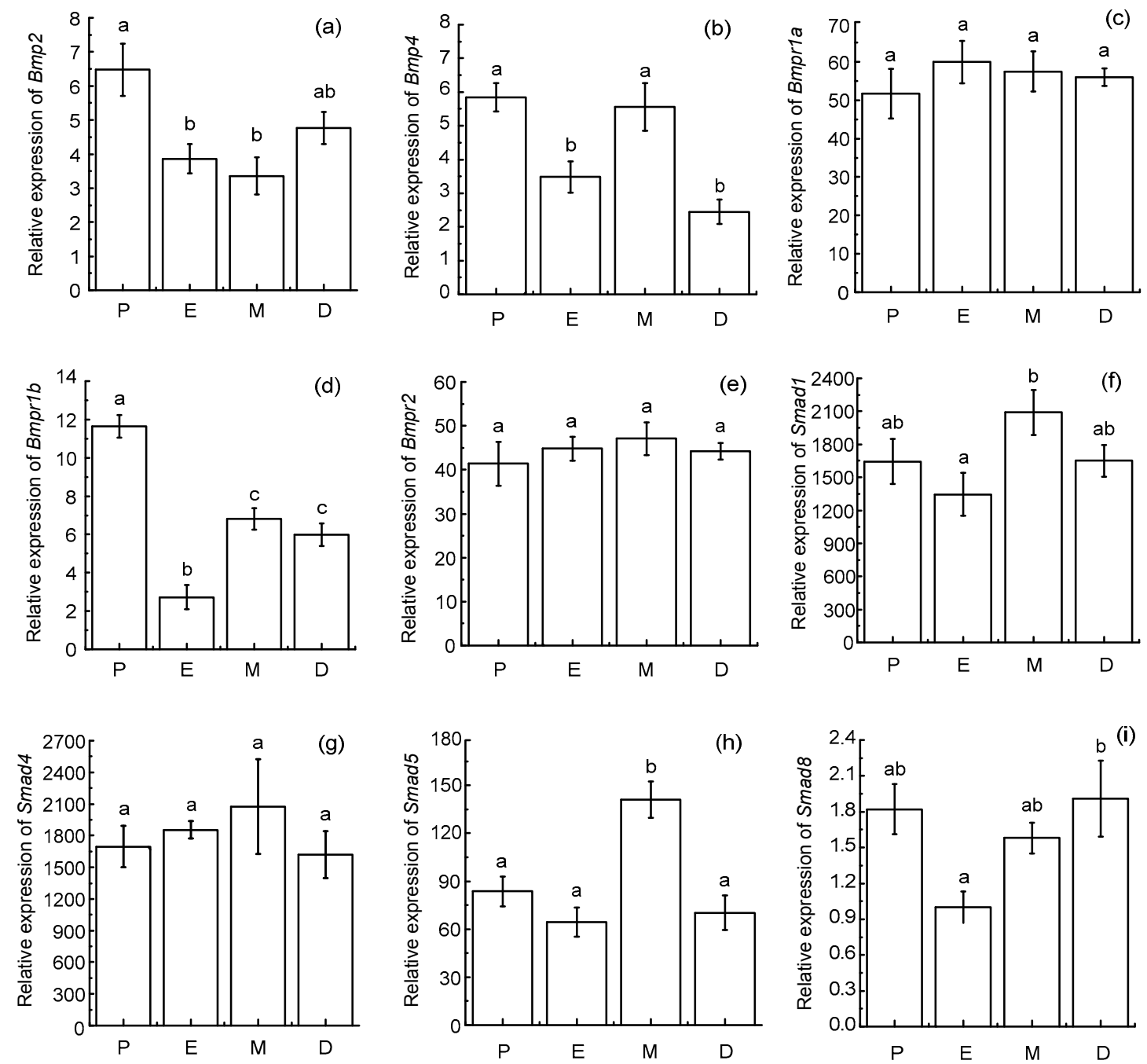

Fig. 1 Changes in mRNA levels for Bmp2, Bmp4, and components of the signaling pathway throughout the estrous cycle

Uterine samples were collected at various stages of the estrous cycle (P: proestrus; E: estrus; M: metestrus; D: diestrus). Total RNA was extracted from all samples, and $1 \mu \mathrm{g}$ total RNA was analyzed by real-time PCR. The relative expression of each gene was standardized to glyceraldehyde-3-phosphate dehydrogenase (Gapdh). Then, all data were normalized on the basis of level of Smad8 mRNA at estrus. All results were presented as mean \pm SEM (at least seven mice each stage). Means identified with the same letter are not significantly different $(P>0.05)$

addition, the expression levels of Smad1 and Smad5 were significantly higher than that of $\operatorname{Smad} 8(P<0.05)$.

\subsection{Immunolocalization of BMP2 protein during the estrous cycle}

To provide more evidence illustrating the important role of BMP signaling during the estrous cycle, the BMP2 protein in the mice uterus was examined using immunohistochemistry. Our results showed that BMP2 protein was detected throughout the estrous cycle (Fig. 2). Specifically, it was moderately immunolocalized to the uterine luminal and glandular epithelial cells at proestrus (Figs. 2a and 2e; Table 3), estrus (Figs. 2b and 2f; Table 3), and diestrus (Figs. 2d and 2h; Table 3), whereas it was weak at metestrus (Figs. 2c and 2g; Table 3). Furthermore, individual stromal cells and myometrium were weakly stained BMP2 protein positive (Fig. 2; Table 3). No specific staining was detected in the negative control sections (Figs. $2 \mathrm{i}$ and $2 \mathrm{j}$ ). 


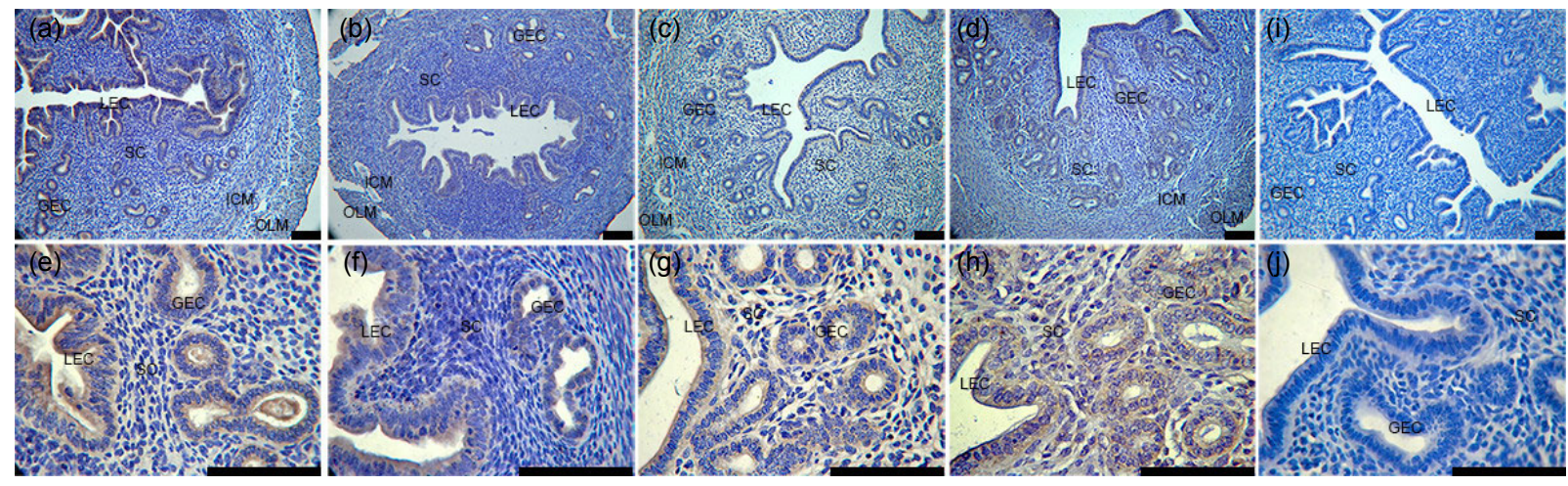

Fig. 2 BMP2 protein in the mouse during the estrous cycle: low magnification (a-d) and high magnification (e-h) Uterine sections were immunostained with a rabbit polyclonal antibody to BMP2 and counterstained with haematoxylin. A positive reaction was observed as brown staining and the counterstaining background appeared blue. BMP2 protein was moderately immunolocalized to the uterine luminal and glandular epithelial cells at proestrus (a, e), estrus (b, f), and diestrus (d, h), whereas it was weak at metestrus (c, g). Furthermore, individual stromal cells and myometrium were weakly stained BMP2 protein positive. Negative control sections showed no specific staining (i,j). LEC: luminal epithelial cells; GEC: glandular epithelial cells; SC: stromal cells; ICM: inner circular smooth muscle layer; OLM: outer longitudinal smooth muscle layer. Scale bar: $10 \mu \mathrm{m}$ (Note: for interpretation of the references to color in this figure legend, the reader is referred to the web version of this article)

Table 3 Relative abundances of BMP2 protein in the mouse uterus during the estrous cycle

\begin{tabular}{lcccc}
\hline \multirow{2}{*}{ Uterine structural component and cell type } & \multicolumn{4}{c}{ Staining intensity } \\
\cline { 2 - 5 } & Proestrus & Estrus & Metestrus & Diestrus \\
\hline Glandular epithelial cell & ++ & ++ & + & ++ \\
Luminal epithelial cell & ++ & ++ & + & ++ \\
Myometrial cell & + & + & + & + \\
Stromal cell & + & + & + & + \\
\hline
\end{tabular}

+: weak staining; ++: moderate staining; +++: strong staining

\section{Discussion}

Our study provided novel information regarding the expression of Bmp2 and Bmp4 members of the BMP family and components of the signaling pathway at the mRNA level in the mouse uterus during the estrous cycle. To minimize individual differences, female Swiss ICR mice of similar age and body weight were used. Our findings strongly suggest that the Bmp2 and Bmp4 signaling pathway might play key roles in the regulation of cyclic changes in the mouse uterus.

A wealth of evidence has indicated that the mRNAs encoding a number of BMP family members are abundantly and dynamically expressed in the murine uterus, and are associated with cell proliferation, differentiation, and apoptosis (Paria et al., 2001; Erickson et al., 2004; Liu et al., 2004; Xia et al., 2005; Li et al., 2007; Large and DeMayo, 2012; Wetendorf and DeMayo, 2012; Nagashima et al., 2013). In our study, we examined the mRNA levels of Bmp2 and Bmp4 during the estrous cycle. Our results showing that the expression level of Bmp2 was significantly higher at proestrus than at estrus and metestrus were inconsistent with Erickson et al. (2004). This inconsistency might be caused by differences between animals and experimental techniques used for study. Bmp2 ablation affects proliferation, differentiation, and apoptosis in the decidualizing uterus (Lee et al., 2007; Franco et al., 2011). Results of in vitro 
experiments had suggested that BMP2 promoted differentiation of endometrial stromal cells (Li et al., 2007). Thus, the expression of Bmp 2 in the uterus implies that BMP2 might have regulatory functions in the degradation and remodeling of the endometrium during the estrous cycle. However, the specific mechanism underlying this effect needs confirmation. In comparison to Bmp2, the relative abundance of Bmp4 showed significant fluctuations, strongly decreasing at estrus and diestrus, and strongly increasing at metestrus. We speculate that the significant change in Bmp4 expression might be tightly correlated with the cyclic changes in the endometrium. This suggestion is nearly identical to that proposed by Tanwar and McFarlane (2011). Increasing evidence suggests that there is a subtle relationship between steroids and BMP signaling. Expression of uterine $B m p 7$ was abolished in response to estradiol treatment in mice (Shimasaki et al., 2004; Tanwar and McFarlane, 2011). Similarly, exogenous treatment with progesterone receptor antagonist RU486 has been shown to markedly down-regulate the level of Bmp 2 mRNA in the decidual uterus (Li et al., 2007). Further studies are needed to confirm a functional link between steroids and BMP signaling in the uterus. Paired-sample $t$-tests revealed that there were no statistically significant differences between the expression levels of Bmp2 and Bmp4, which suggests the possibility that both play important roles in the control of uterine functions. Collectively, these findings suggest that both Bmp2 and Bmp4 might contribute to the degradation and remodeling of the endometrium during the estrous cycle.

BMP receptors are essential mediators of BMP signal transduction from the cell surface to the cytoplasm. BMPR1A and BMPR1B are receptors specific for BMP2 and BMP4, whereas BMPR2 appears to bind exclusively to BMP ligands among all BMP receptors identified in mammals (Shimasaki et al., 2004; Miyazono et al., 2010). Although much is known about BMP receptors, little is known about their roles. In the current study, the mRNA levels of the three Bmprs were confirmed by real-time PCR. Bmprla and Bmpr2 showed extremely stable expression during an entire estrous cycle. Our findings suggest that both Bmprla and Bmpr2 are constitu- tively expressed in the uterus. In contrast, we found that the level of Bmpr $1 b$ mRNA appeared to change significantly throughout the estrous cycle. The stage-specific changes in Bmpr $1 b$ mRNA expression might be closely associated with the growth and development of the endometrium (Kim et al., 2003; Erickson et al., 2004). In support of this deduction, mice deficient in Bmprlb exhibited a failure in endometrial gland formation and severe destruction of the uterine structure (Yi et al., 2001). Furthermore, our results showed that the level of Bmpr $1 b$ mRNA was significantly lower than that of Bmprla and Bmpr 2 mRNA. In situ hybridization results showed that Bmprla and Bmpr2 mRNA appeared to be widely presented in the endometrium and myometrium, whereas Bmprlb message was restricted to the luminal and glandular epithelial cells (Erickson et al., 2004). Thus, epithelial restricted expression of Bmprlb could be one of the reasons for the low expression level of Bmprlb compared to Bmprla and Bmpr2. Our findings, together with the studies cited above, suggest that Bmprlb is essential for maintenance of normal uterine functions. Our results strongly suggest that three murine BMP receptors differentially contribute to the control of growth and development of the endometrium during the estrous cycle.

Smad1, Smad5, and Smad8 are R-Smads mediating the intracellular signaling of BMP. Earlier studies have reported their critical functions in different models (Chen et al., 1997; Chang et al., 1999; Ying and Zhao, 2000; Huang et al., 2009). However, there is a lack of understanding of the role of each $R$-Smad in the mouse uterus during the estrous cycle. Our results showed that all the three R-Smads were differentially expressed in the mouse uterus, demonstrating their differing roles during the estrous cycle. Further analysis revealed that the expression levels of Smad1 and Smad5 were significantly higher than that of Smad8. Thus, we conjecture that Smad1 and Smad5 are the predominant $R$-Smads involved in the regulation of uterine function during the estrous cycle. Our results revealed also that $\mathrm{Smad} 4$ was highly expressed throughout the estrous cycle. Our results are largely similar to those of previous works (Lin et al., 2004; Liu et al., 2004). The marked expression of Smad4 
might be closely correlated with its molecular roles. $S m a d 4$, a common partner for all R-Smads, works through combination with $R$-Smads to control gene transcription (Wan et al., 2002; Shimasaki et al., 2004). Combining the relative level of Smad4 in the current study with previous results in rodents, we speculate that the persistent and high-level expression of Smad4 in the uterus is an essential factor for mediation of BMP signal during the estrous cycle.

We investigated the immunolocalization of BMP2 protein using immunohistochemistry. Our observation that BMP2 protein was localized mainly in the uterine luminal and glandular epithelial cells throughout the estrous cycle appears to contrast with the results of Erickson et al. (2004). This discrepancy might be a result of differences between animals and experimental techniques. Our findings demonstrated that both uterine luminal and glandular epithelium were primary targets for BMP signaling. Differences in the staining intensity of BMP2 protein were observed during different stages of the estrous cycle. Thus, we surmised that BMP2 protein contributed to the degradation and remodeling of the endometrium in a stage-specific manner.

\section{Conclusions}

In conclusion, we detected the temporal expression patterns of Bmp2 and Bmp4 members of the BMP family and components of the signaling pathway in the mouse uterus during the estrous cycle. Also, we examined the histological location of BMP2 protein using immunohistochemistry. Our results provide information about the variation in the mRNA levels of Bmp2 and Bmp4 and components of the BMP signaling pathway. Our findings also provide quantitative and useful information about the roles of endometrial BMP proposed and demonstrated by others, such as the degradation and remodeling of the endometrium.

\section{Acknowledgements}

We sincerely thank Dr. Reinhold J. HUTZ of the Department of Biological Sciences, University of WisconsinMilwaukee, USA, for reading the original manuscript and providing valuable suggestions.

\section{Compliance with ethics guidelines}

Yan LI, Quan-wei WEI, Jian-gang FENG, Mu-lin XU, Rui-hua HUANG, and Fang-xiong SHI declare that they have no conflict of interest.

All institutional and national guidelines for the care and use of laboratory animals were followed.

\section{References}

Abdallah, Y., Naji, O., Saso, S., et al., 2012. Ultrasound assessment of the peri-implantation uterus: a review. Ultrasound Obstet. Gynecol., 39(6):612-619. [doi:10. 1002/uog.10098]

Aoki, H., Fujii, M., Imamura, T., et al., 2001. Synergistic effects of different bone morphogenetic protein type I receptors on alkaline phosphatase induction. J. Cell Sci., 114(8):1483-1489.

Argañaraz, M.E., Apichela, S.A., Kenngott, R., et al., 2013. Expression and localization of nodal in bovine oviduct and uterus during different functional stages of oestrus cycle and pregnancy. Histochem. Cell Biol., 139(1):89-97. [doi:10.1007/s00418-012-1030-4]

Bruce, D.L., Sapkota, G.P., 2012. Phosphatases in SMAD regulation. FEBS Lett., 586(14):1897-1905. [doi:10. 1016/j.febslet.2012.02.001]

Bukowska, D., Kempisty, B., Jackowska, M., et al., 2011. Differential expression of epidermal growth factor and transforming growth factor beta isoforms in dog endometrium during different periods of the estrus cycle. Pol. J. Vet. Sci., 14(2):259-264. [doi:10.2478/v10181011-0039-2]

Cai, J., Pardali, E., Sanchez-Duffhues, G., et al., 2012. BMP signaling in vascular diseases. FEBS Lett., 586(14): 1993-2002. [doi:10.1016/j.febslet.2012.04.030]

Chang, H., Huylebroeck, D., Verschueren, K., et al., 1999. Smad5 knockout mice die at mid-gestation due to multiple embryonic and extraembryonic defects. Development, 126(8):1631-1642.

Chen, Y., Bhushan, A., Vale, W., 1997. Smad8 mediates the signaling of the ALK-2 receptor serine kinase. PNAS, 94(24):12938-12943.

Dey, S.K., 2004. Focus on implantation. Reproduction, 128(6): 655-656. [doi:10.1530/rep.1.00537]

Ding, W., Zhang, W., Hui, F.M., et al., 2012. Cell-specific expression and immunolocalization of nitric oxide synthase isoforms and soluble guanylyl cyclase $\alpha_{1}$ and $\beta_{1}$ subunits in the ovary of fetal, neonatal and immature pigs. Anim. Reprod. Sci., 131(3-4):172-180. [doi:10.1016/j. anireprosci.2012.02.013]

Erickson, G.F., Fuqua, L., Shimasaki, S., 2004. Analysis of spatial and temporal expression patterns of bone morphogenetic protein family members in the rat uterus over the estrous cycle. J. Endocrinol., 182(2):203-217. [doi:10. 1677 joe.0.1820203] 
Fernandez-Valdivia, R., Mukherjee, A., Amato, P., et al., 2007. Progesterone-action in the murine uterus and mammary gland requires steroid receptor coactivator 2: Relevance to the human. Front. Biosci., 12(8-12):3640-3647. [doi: $10.2741 / 2340]]$

Franco, H.L., Jeong, J.W., Tsai, S.Y., et al., 2008. In vivo analysis of progesterone receptor action in the uterus during embryo implantation. Semin. Cell Dev. Biol., 19(2): 178-186. [doi:10.1016/j.semcdb.2007.12.001]

Franco, H.L., Dai, D., Lee, K.Y., et al., 2011. Wnt4 is a key regulator of normal postnatal uterine development and progesterone signaling during embryo implantation and decidualization in the mouse. FASEB J., 25(4):1176-1187. [doi:10.1096/fj.10-175349]

Hu, J., Zhang, Y.Q., Liu, X.P., et al., 2003. Expression and localization of Smad1, Smad2 and Smad4 proteins in rat testis during postnatal development. Asian J. Androl., 5(1):51-55.

Huang, Z., Wang, D., Ihida-Stansbury, K., et al., 2009. Defective pulmonary vascular remodeling in Smad8 mutant mice. Hum. Mol. Genet., 18(15):2791-2801. [doi:10. 1093/hmg/ddp214]

Jones, R.L., Stoikos, C., Findlay, J.K., et al., 2006. TGF- $\beta$ superfamily expression and actions in the endometrium and placenta. Reproduction, 132(2):217-232. [doi:10. 1530/rep.1.01076]

Kim, J.G., Song, J.H., Vallet, J.L., et al., 2003. Molecular characterization and expression of porcine bone morphogenetic protein receptor-IB in the uterus of cyclic and pregnant gilts. Biol. Reprod., 68(3):735-743. [doi:10. 1095/biolreprod.102.008433]

Kong, S., Zhang, S., Chen, Y., et al., 2012. Determinants of uterine aging: lessons from rodent models. Sci. China Life Sci., 55(8):687-693. [doi:10.1007/s11427-012-4356-1]

Large, M.J., DeMayo, F.J., 2012. The regulation of embryo implantation and endometrial decidualization by progesterone receptor signaling. Mol. Cell. Endocrinol., 358(2): 155-165. [doi:10.1016/j.mce.2011.07.027]

Lee, K.Y., Jeong, J.W., Wang, J., et al., 2007. Bmp2 is critical for the murine uterine decidual response. Mol. Cell. Biol., 27(15):5468-5478. [doi:10.1128/MCB.00342-07]

Li, Q., Kannan, A., Wang, W., et al., 2007. Bone morphogenetic protein 2 functions via a conserved signaling pathway involving Wnt4 to regulate uterine decidualization in the mouse and the human. J. Biol. Chem., 282(43): 31725-31732. [doi:10.1074/jbc.M704723200]

Li, Y., Zhou, X., Wei, Q.W., et al., 2014. Cell-specific expression and immunolocalization of nitric oxide synthase isoforms and soluble guanylyl cyclase $\alpha$ and $\beta$ subunits in postnatal porcine uteri. Acta Histochem., 116(3):466-473. [doi:10.1016/j.acthis.2013.10.003]

Lin, H.Y., Wang, H.M., Li, Q.L., et al., 2004. Expression of $S m a d 2$ and Smad4, transforming growth factor- $\beta$ signal transducers in rat endometrium during the estrous cycle, pre-, and peri-implantation. Anim. Reprod. Sci., 80(3-4): 303-316. [doi:10.1016/S0378-4320(03)00171-4]

Liu, G., Lin, H., Zhang, X., et al., 2004. Expression of Smad2 and Smad4 in mouse uterus during the oestrous cycle and early pregnancy. Placenta, 25(6):530-537. [doi:10.1016/j. placenta.2003.11.006]

Massague, J., Seoane, J., Wotton, D., 2005. Smad transcription factors. Genes Dev., 19(23):2783-2810. [doi:10.1101/gad. 1350705]

Miyazono, K., Kamiya, Y., Morikawa, M., 2010. Bone morphogenetic protein receptors and signal transduction. J. Biochem., 147(1):35-51. [doi:10.1093/jb/mvp148]

Nagashima, T., Li, Q., Clementi, C., et al., 2013. BMPR2 is required for postimplantation uterine function and pregnancy maintenance. J. Clin. Invest., 123(6):2539-2550. [doi:10.1172/JCI65710]

Omwandho, C.O., Konrad, L., Halis, G., et al., 2010. Role of TGF- $\beta \mathrm{s}$ in normal human endometrium and endometriosis. Hum. Reprod., 25(1):101-109. [doi:10.1093/humrep/ dep382]

Pangas, S.A., 2012. Bone morphogenetic protein signaling transcription factor (SMAD) function in granulosa cells. Mol. Cell Endocrinol., 356(1-2):40-47. [doi:10.1016/j. mce.2011.06.021]

Paria, B.C., Ma, W.G., Tan, J., et al., 2001. Cellular and molecular responses of the uterus to embryo implantation can be elicited by locally applied growth factors. PNAS, 98(3):1047-1052. [doi:10.1073/pnas.98.3.1047]

Shi, F., Stewart, R.L.Jr., Perez, E., et al., 2004. Cell-specific expression and regulation of soluble guanylyl cyclase $\alpha_{1}$ and $\beta_{1}$ subunits in the rat ovary. Biol. Reprod., 70(6): 1552-1561. [doi:10.1095/biolreprod.103.025510]

Shimasaki, S., Moore, R.K., Otsuka, F., et al., 2004. The bone morphogenetic protein system in mammalian reproduction. Endocr. Rev., 25(1):72-101. [doi:10.1210/er.20030007]

Shimizu, T., Yokoo, M., Miyake, Y., et al., 2004. Differential expression of bone morphogenetic protein 4-6 (BMP-4, -5 , and -6 ) and growth differentiation factor-9 (GDF-9) during ovarian development in neonatal pigs. Domest. Anim. Endocrinol., 27(4):397-405. [doi:10.1016/j. domaniend.2004.04.001]

Tanwar, P.S., McFarlane, J.R., 2011. Dynamic expression of bone morphogenetic protein 4 in reproductive organs of female mice. Reproduction, 142(4):573-579. [doi:10. 1530/REP-10-0299]

Wan, M., Cao, X., Wu, Y., et al., 2002. Jabl antagonizes TGF- $\beta$ signaling by inducing Smad4 degradation. EMBO Rep., 3(2):171-176. [doi:10.1093/embo-reports/kvf024]

Wen, X., He, J., Zhang, X., et al., 2011. Localization of Smad4 in the ovary of the European hedgehog (Erinaceus europaeus L.). Acta Histochem., 113(3):382-386. [doi:10. 1016/j.acthis.2009.12.004]

Wetendorf, M., DeMayo, F.J., 2012. The progesterone 
receptor regulates implantation, decidualization, and glandular development via a complex paracrine signaling network. Mol. Cell Endocrinol., 357(1-2):108-118. [doi:10.1016/j.mce.2011.10.028]

Xia, Y., Sidis, Y., Mukherjee, A., et al., 2005. Localization and action of Dragon (repulsive guidance molecule b), a novel bone morphogenetic protein coreceptor, throughout the reproductive axis. Endocrinology, 146(8):3614-3621. [doi:10.1210/en.2004-1676]
Yi, S.E., Lapolt, P.S., Yoon, B.S., et al., 2001. The type I BMP receptor BmprIB is essential for female reproductive function. PNAS, 98(14):7994-7999. [doi:10.1073/pnas. 141002798]

Ying, Y., Zhao, G.Q., 2000. Detection of multiple bone morphogenetic protein messenger ribonucleic acids and their signal transducer, Smad1, during mouse decidualization. Biol. Reprod., 63(6):1781-1786. [doi:10.1095/biolreprod 63.6.1781]

\section{中文衉要:}

\section{本文题目：BMP2, BMP4及 BMP 信号通路相关成员在发情周期小鼠子宫中的表达}

Expression of bone morphogenetic protein 2, 4, and related components of the BMP signaling pathway in the mouse uterus during the estrous cycle

研究目的: 研究骨形态发生蛋白 (BMP) 2, 4及 BMP 信号通路相关成员在发情周期小鼠子宫中的表达 模式。

创新要点: 运用实时荧光定量聚合酶链式反应 (PCR) 系统地研究了 $B m p 2$ 和 $B m p 4$ 及其 BMP 信号通路 相关成员在小鼠子宫中 mRNA 水平表达模式, 同时运用免疫组化方法研究了 BMP2蛋白在 小鼠子宫中的定位模式。

研究方法：收集发情周期各个时期小鼠子宫, 一侧子宫角咜存于液氮或 $-80{ }^{\circ} \mathrm{C}$ 冰箱用于实时苂光定量 PCR，另一侧子宫角用 $40 \mathrm{mg} / \mathrm{ml}$ 多聚甲醛固定用于 BMP2蛋白免疫组化定位。

重要结论: 实时苂光定量 PCR 结果表明, Bmp2的表达水平在发情前期显著高于发情期和发情后期 $(P<0.05), B m p 4$ 的表达水平呈现显著波动, 但 Bmp2与 Bmp4差异不显著 $(P>0.05)$ 与 Bmprla 和 $B m p r 2$ 的表达水平在整个发情周期无显著变化 $(P>0.05)$ 。然而, $B m p r l b$ 的 mRNA 水平 在发情期显著下降 $(P<0.05)$, 在发情后期上升。此外, Bmpr $1 b$ 的 mRNA 水平显著低于相 应时期 Bmprla 和 Bmpr 2 的 mRNA 水平 $(P<0.05)$ 。三种 $R$-Smads 差异地表达于小鼠子宫, 并且 $S m a d 1$ 和 $S m a d 5$ 的表达水平显著高于 $\operatorname{Smad} 8(P<0.05)$ 。此外, $S m a d 4$ 的表达水平在整 个发情周期无显著变化。免疫组化结果显示, BMP2蛋白在整个发情周期差异表达, 并主要 定位于子宫腔上皮细胞和腺上皮细胞。我们的结果提供了 BMP2和 BMP4及其 BMP 信号通 路相关成员 mRNA 水平表达变化信息, 这些数据为论证 BMP 在子宫内膜中的作用如子宫 内膜的退化与重塑提供量化和有用的信息。

关键词组：骨形态发生蛋白；骨形态发生蛋白受体；SMAD蛋白；子宫；发情周期 